\title{
Traditional Land Practice and Forest Conservation: Case Study of The Manggarai Tribe in Ruteng Mountains, Indonesia
}

\author{
Elisa Iswandono ${ }^{1 凶}$, Ervizal A.M. Zuhud ${ }^{1}$, Agus Hikmat ${ }^{1}$, Nandi Kosmaryandi ${ }^{1}$, Lukas R. Wibowo ${ }^{2}$ \\ ${ }^{1}$ Institut Pertanian Bogor, Indonesia \\ ${ }^{2}$ Research scientist at Forest Research Development Agency (FORDA)
}

DOI: http://dx.doi.org/10.15294/komunitas.v8i2.4945

Received : 27 JAnuary 2016; Accepted: 19 August 2016; Published: 30 September 2016

\begin{abstract}
Conservation of mountain forests in the tropics will be successful if the interests of local communities considered in the management. Indigenous system of forest management for the sustainable use is the most appropriate for better understanding to the environmental conditions. This study is aimed at analyzing the traditional land management by Manggarai communities and integrate this local wisdom in to the forest conservation. This research is a qualitative ethnographic approach. Qualitative data in 2014 obtained through observation, interviews, data from relevant agencies and related literature. The results showed that traditional land management and sustainable use zoning system have been practiced by the Manggarai community in Ruteng Mountains. Indigenous land use practice is done by considering the sustainability and preventing land degradation.
\end{abstract}

Keywords: forest conservation; integration; local people; Manggarai Tribe; traditional

\section{INTRODUCTION}

Local communities in Indonesia have a role in conservation through traditional land management which is inherited from generation to generation. The life patterns derived from the value of culture, religion and customs that make up the values of local wisdom, one of which is local wisdom in land management. Diverse communities have an unique type of ecosystem diversity, work, routine, customs, needs and ideas on how to address the phenomenon of the surrounding natural environment (Agarwal 2009). For hundreds of years of experience provides unique and specific ideas about the reciprocal relationship between the community and the environment. Some examples of local wisdom in traditional land management in Indonesia i.e. the customary forest management in Ammatoa South Sulawesi (Dassir 2008), Krui Lampung (Vitello

Corresponding author :

Address: Dramaga Main Road, Campus IPB Dramaga, Bogor, 16680, Indonesia

Email : eiswandono@gmail.com
2002), Baduy Banten (Senoaji 2011) and indigenous peoples in the Wasur National Park and Kayan Mentarang (Kosmaryandi 2012). This study took a sample of the Manggarai community in the mountains of Ruteng.

The system of forest management by local communities is the most appropriate for sustainable use because of the local community have a better understanding to the environmental conditions and based on the lifestyle that values local religious (Zent 2009, p.12-15; Berkes and Turner 2006; Brook and McLachlan 2008). Managers of conservation area should ensure that the interests of local communities for current and future through forest management program aligned with the interests of local communities (Anderson and Putz 2002; Weyerhaeuser 2005; Zapf 2005). The community perceptions of the ecological is formed through a process of adaptation and inherited through

(C) 2016 Semarang State University. All rights reserved p-ISSN 2086 - 5465 | e-ISSN 2460-7320

UNNDS JOURNALS


the issues and myths because people can not explain logically the phenomenon of the natural environment. One of the causes of forest degradation is a loss of a relationship or interaction between local people who have culturally specific about the environment with the environment (Camacho et al. 2012; Charnley 2007; Coombe 2005; Herrmann 2006; Persha et al. 2011). Traditional knowledge in Manggarai decreased especially in the younger generation (Iswandono et al. 2015b). The decline of traditional knowledge is an indicator of forest degradation due to the decline of how to manage land sustainably so it is necessary to documenting and to be integrated in conservation.

Forest conservation efforts without accommodating the interests of local communities in the long term will be less successful so that besides the strict protection of the forests, needed an integrated concept between forest conservation and sustainable management of traditional lands. This study is an effort to conserve the forest ecosystems of the mountains to the existence of local communities that exist around the forest. The purpose of this study is to analyze the forms of traditional land management Manggarai tribal community and integrate into forest conservation.

\section{METHODS}

This research was carry out for 6 months from July to December 2014 in Ruteng Mountains. There are 70 villages around $\mathrm{Ru}-$ teng Forests and 22 villages around Forest Todo. The location of the study site includes three kampongs (small traditional villages), two villages located in the Ruteng Forest and the other village in the enclave of Todo forest (Figure 1). All three villages were chosen for the sameness of the ethnicity, language, culture and forest ecosystem.

The research data in the form of ethnographic data that revealed 9 factors, namely the location of the natural environment and demographics, the origin and history of the tribe, language, technology systems, livelihood systems, social organization, systems of knowledge, art and technology systems (Koentjaraningrat 2002, p.329-381). Acquisition of data through participant observation, focus group discusion (FGD), in-dept interviews, and literature. Interviews using open-ended interviews with informants set based on the status and role in the community by purposive and snowball (Sugiyono 2010, p.156-167).

Determination of informants purposively based on initial guidelines one informant who recommend other informant (snowball approach). Informants in 3 kampong's are 5 persons, consisting of kampong's leader (tua golo), traditional leader's who divide communal land (tua teno), and people who get forest products.

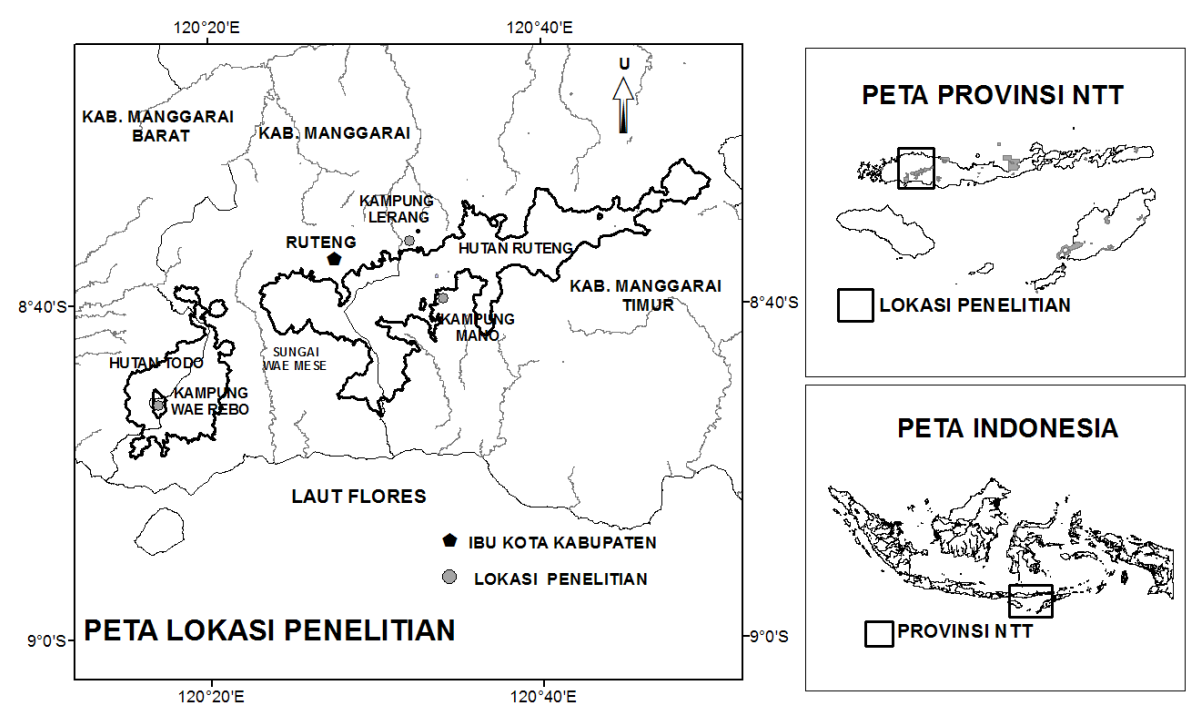

Figure 1. Study Site 
Interviews were conducted in an open area in the yard, garden, forest, and on the edge lake to make respondents feel free. In addition to village communities, open ended interviews were conducted also with the 2 leaders of local NGOs, namely and Sanggar Lawe Lenggong which is working in conservation and culture, and also 2 people Manggarai District local officials who understand the culture of conservation with assistance locals.

This study use surveying equipment such as: a map of the working area, recorders, global positioning system (GPS), digital cameras and questionnaire. Mapping land used an overlay of several maps, i.e. mental map, map forest areas, contours and streams which are processed using software ArcGIS 10.1. Mapping land management by the public (mental map) obtained by making geographic coordinates using GPS and ground check. The Overview of community land management is the result of interviews and mapping with geographic coordinates that illustrate the distribution and utilization of comunal lands in detail.

\section{RESULTS AND DISCUSSION}

\section{The Belief to the Nature and Environ- ment}

According to the Manggarai community, the universe is a creation of Mori Keraeng as the highest form of Manggarai. Mori Keraeng is the creator of heaven, earth, sun, moon and the entire universe. Mori Keraeng is not a genuine belief of Manggarai but influence from Bugis when the Manggarai occupied by the kingdom of Goa. Mori means lord and Keraeng means king, so Mori Keraeng means God is King. This belief is the influence of monotheism that God is the Lord of the entire universe (Verheijen 1991, p.37-38). In everyday practice, this faith have acculturation with local beliefs so that in addition to Mori Keraeng, they also worship to local goddess.

The earth in the perceptions of Manggarai community is the mother that produce food, so it must be respected, treated well and sacred. At the opening of agricultural land and the digging of pit tomb, performed a traditional ceremony to worship the guardian spirit of the land. The sky is the father who gives rain for the fertility of the soil. Forests are the daughter of a marriage between heaven and earth, in Manggarai it called "anak rona". "Anak rona" in Manggarai culture is a descendant of the woman that must be respected so that according to this concept the local community have to have traditional ceremonies called "roko molas poco". "Roko molas poco" is a traditional ceremony to propose big tree like propose a beautiful girl to be the main pillar for the traditional house.

\section{Social Structure and Tenure}

The leadership of tua golo in customs enforcement aided by tu'a teno that have a duty to divide communal land and resolving land boundaries and some tu'a panga who is the leader of the lineage that oversees several tu'a kilo which is leaders of several families (Figure 2). The original tenure system of Manggarai community is the small village or "beo" that usually located in a flat area at the top of a hill or "golo" led by a village head called tu'a golo. The wider land tenure systems such as gelarang (village), kedaluan (sub-district) and adak (kingdom) is the influence from Bima Kingdom (Lawang 2004, p.116-132). The leadership of "tua golo" in the customary enforcement aided by "tu'a teno" that have a duty to divide communal land and resolving land boundaries and some tu'a panga who is the leader of the lineage that oversees several people called "tu'a kilo" which is leaders of several families.

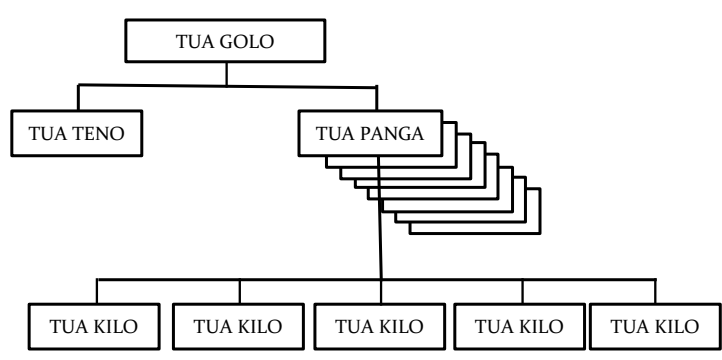

Figure 2. The institutional structure of the customary community of Manggarai

Traditional leadership is still influen- 
tial in the community, especially in suburb the town of Ruteng, Manggarai district center even though the village administration system has been established long time ago but it only plays a role in the administrative process. Tua golo is more dominant leadership when there are problems in community and the village head more involved in administrative activities (Iswandono et al. 2015a). Beo community recognizes the leadership of "tua golo", especially during traditional rituals penti, barong wae, barong Lodok and other traditional problem solving. The three ceremony is the main traditional ceremony that have to be done by every traditional village in Manggarai.

Penti ceremony is the ceremony of new year celebrations in calendar Manggarai that marks the beginning of the rainy season and seasons to grow food crops such as rice, corn and other food crops. Penti ceremony has a different time every village depends on the timing of early rain season. Barong wae is a traditional ceremony to worship the guardian spirit at wellspring, and barong Lodok to worship the spirit in the communal of land (lingko) (Verheijen 1991, p.41-244).

\section{The neighborhood around the settle- ment and Sustainable Land Manage- ment}

Montane rain forest in the area of Flores Island is only found in Ruteng forests and forest Todo as the biodiversity hot spots and the widest of wet area in the region of Nusa Tenggara. Both of the forest is located in the Ruteng mountains separated by the Wae Mese river (Trainor and Lesmana 200o, p.181-187).

Ruteng mountain forest ecosystems are very sensitive degraded. The type of soil derived from volcanic material that has undergone further development (ultisol, andosol, inceptisol) and without (entisols). Chemical soil fertility is low but good soil physical characteristics. Most of the mountainous landscape have a slope gradient of more than $60 \%$. The slope of the high rainfall was also high $( \pm 2500 \mathrm{~mm} /$ year$)$ have a high risk of erosion (Djuwansah and Suriakusumah 1998, p.145-163). Most of $\mathrm{Ru}-$ teng mountainous region covered by prima- ry and secondary forests (Iswandono et al. 2015a) that plays an important role in preventing soil erosion, and maintaining the sustainability of water resources of surface and ground water. The pressure on forests in the mountains Ruteng primarily agricultural expansion, logging, mining stone and sand (Sinu et al. 1999, p.48).

Manggarai settlements located in the mountainous region for avoiding war with the Sultanate of Bima and Goa in the past (Verheijen 1991, p.23-24), while the coastal areas today generally inhabited by people of Bima, Bugis, Buton and Bajo. The settlement is ussually along the road and follow the village roads and paved highways, but the villages original circular shape is maintained. The existence of the original village is still important as a place to perform rituals "penti".

Manggarai community was originally shifting cultivators in a subsistence. Currently, the crop rotation system can still be found in the village Wae Rebo because it is still the availability of agricultural land. In addition, they are also hunting, fishing and gathering of forest products as well as livestock, especially pigs and chickens.

The agricultural systems today are agroforestry with coffee plants as the main crop.In the area of kampong Mano, cloves as the major producer of Manggarai are planted in the yard around the house. Food species are cultivated as many as 45 species (Wawo 1998, p.51-77), while from the forest as many as 40 species (Iswandono et al. 2015b). Community uses sengon (Albizia falcataria) as coffee shade trees and forest plants thus indirectly do domestication of the species of forest trees.

Villages in the study area is located at an altitude of between 900 up to $1300 \mathrm{~m}$ altitude, topography is hilly with a flat slope up steeply. Small rivers that flow throughout the year. Substitution of the rainy season and the dry season is uncertain but it generally rains started in September through April for \pm 8 months.

The original home of the Manggarai is a wooden house and has a roof of palm fiber. According to the elders story, Before 1950, There are plenty of palm trees (Arenga pin- 


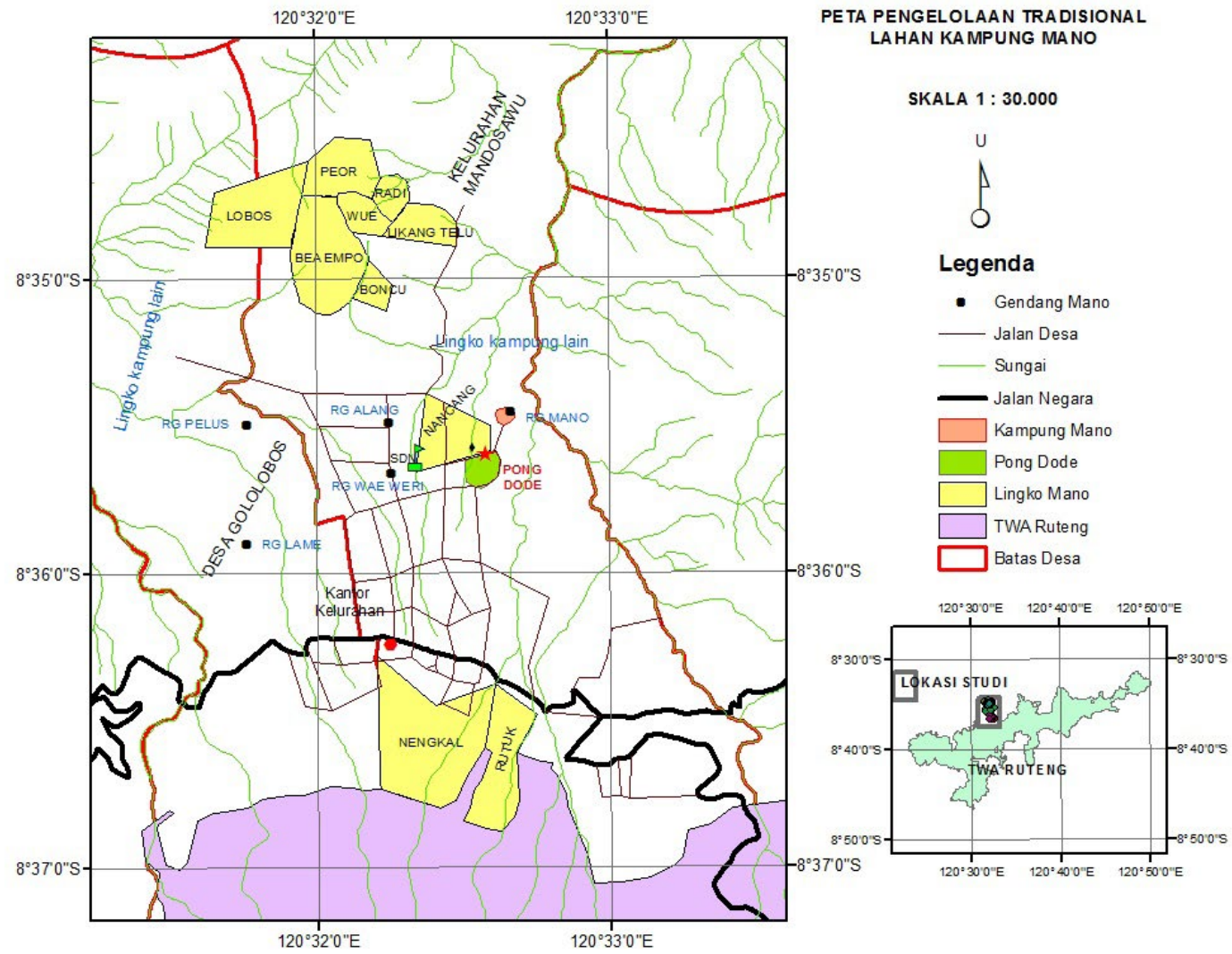

Figure 3. Map of Mano village conditions

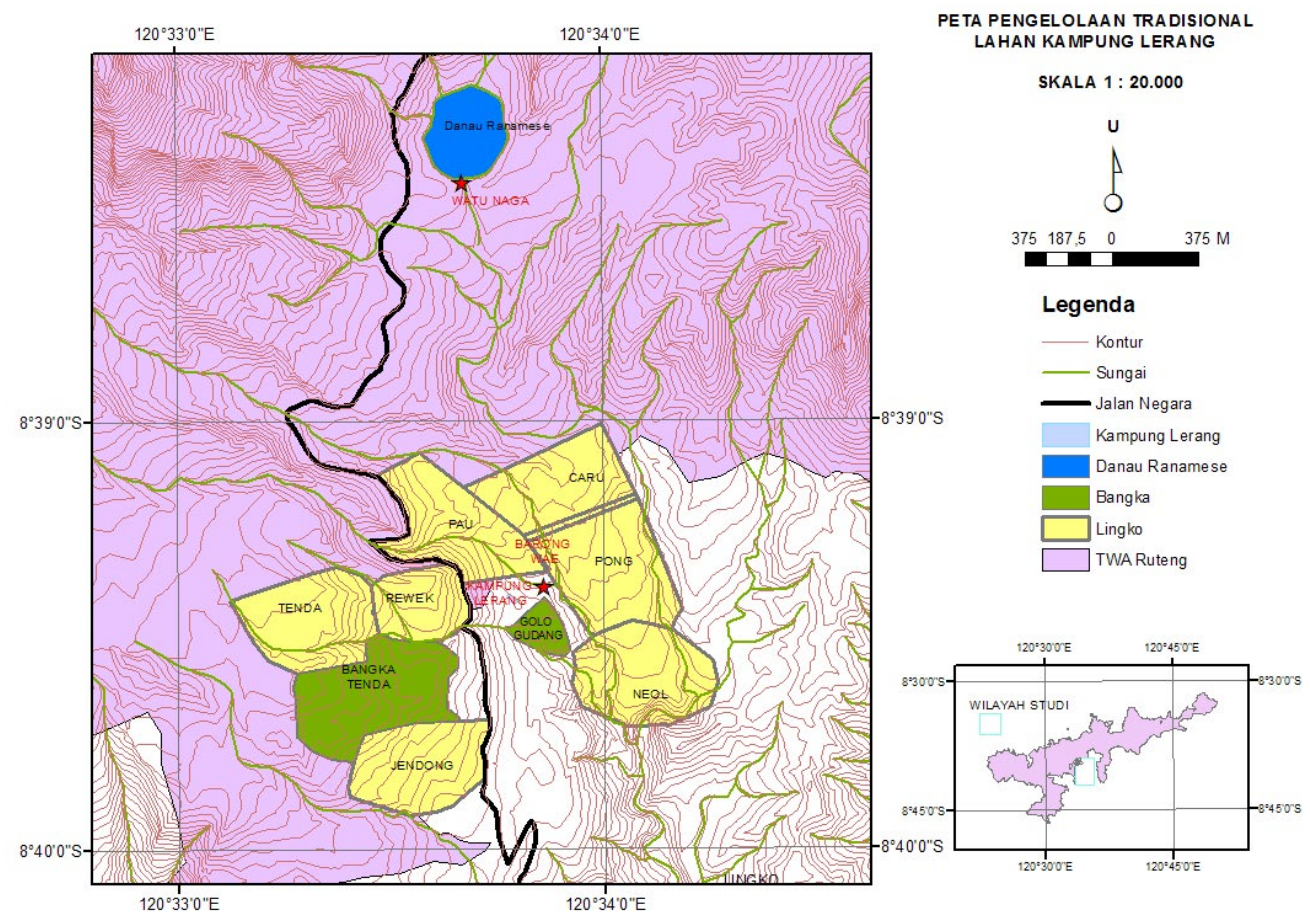

Figure 4. Map of Lerang village conditions. 


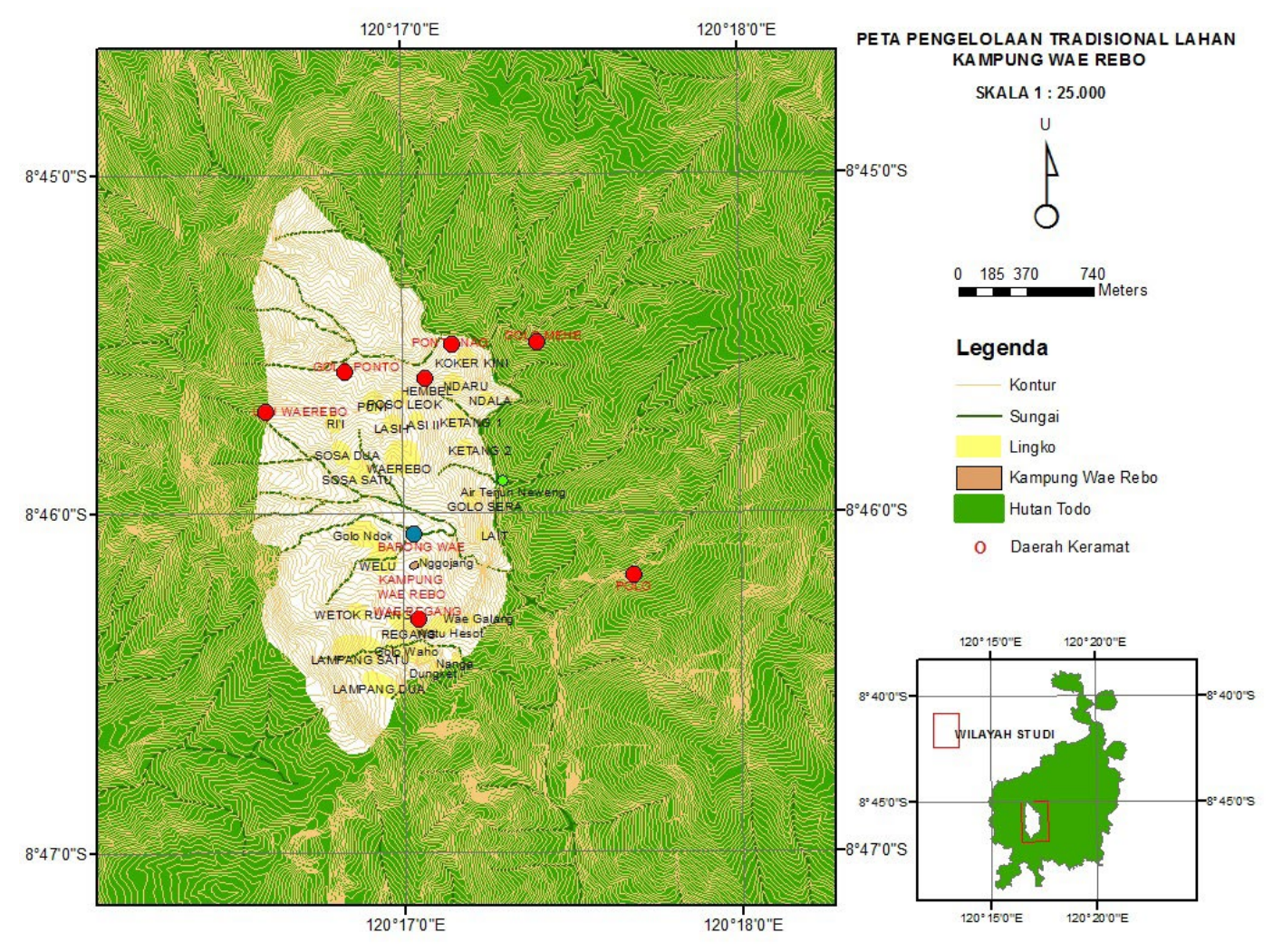

Figure 5. Map of Wae Rebo village conditions.

nata) grew in the Manggarai district which the leaves used for the roof of the house. Around 1950 to 1960 there was hunger that causes people forced to cut down the palm trees (Arenga pinnata) to be made sago. Since then, the housing is no longer have palm leaves for roof. Most custom homes in the villages of native Manggarai roof are made of zinc.

The traditional house of Manggarai are called "mbaru gendang" which has the original shape in Wae Rebo village. "Mba$r u$ gendang" is a traditional house for the indigenous leaders and their families. It is called gendang (drum) because there are eight drum in the custom house symbolizing the eight directions. "Mbaru gendang" is a place to organize the implementation of customary law and the division of the communal garden with the principle "gendang one lingko pe'ang" which means if there is "mbaru gendang" (a custom house), around mbaru gendang is communal land which called lingko. Mbaru gendang with a conical roof almost touched the ground, first floor height of about 1.5 meters is made of timber. Currently, the custom home building in addition to Wae Rebo village is no longer use a special timber. The change because of the difficulty to obtain timber according to the custom home construction. The building is already using a tin roof and walls to replace the wooden planks. This is consistent with the findings of Dewa (1993) at tribe of Lio and Iwanggete in Ende - Flores that they already use building wall as custom home that was initially affected by the construction of the church.

Changes in building materials as well as a ban on the felling of trees in the forest affect the loss of a custom home construction ceremony "roko molas poco", the ceremonial for cutting trees worok (Dysoxylum nutans (Blume) Miq) to be a main pillar. Wood for custom home have started using wood gardens such as ampupu (Eucalyptus urophylla (ST Blake)) and Moak (Arthocarpus integra (JR Forster \& G Forster) on the condition that grows naturally. The ceremony "roko molas poco" accomplished first by 


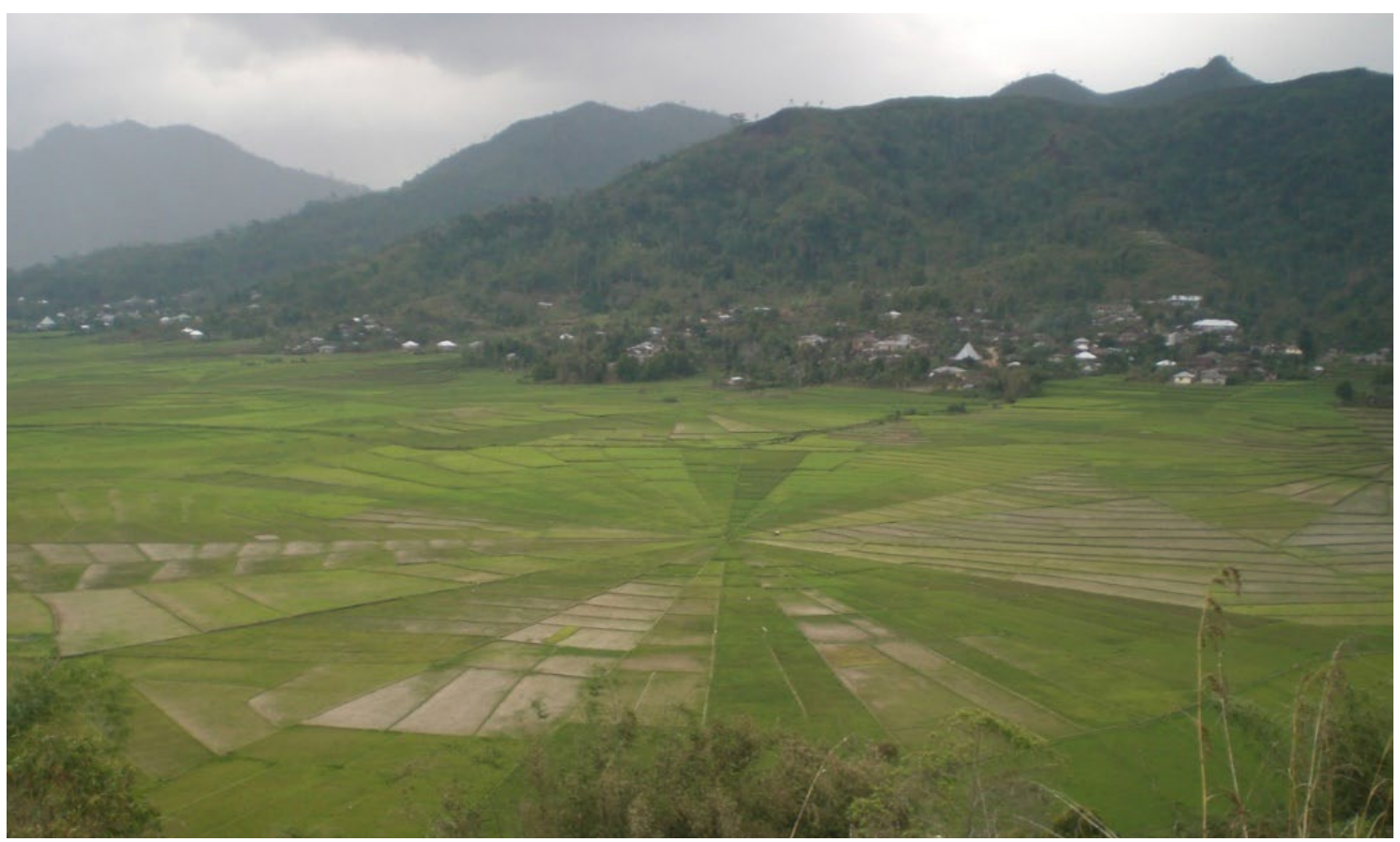

Figure 6 . The system of communal land subdivision (lingko)

bringing the trunk of the tree into the forest for ceremony.

Traditional land management system have religious values that are reflected in local zoning to prevent forest degradation. Sacred forests (cengit pong) is a forest that is not used in addition to traditional ceremonies. Sacred forests is the protection of springs for "wae barong" ceremony. Barong wae belief cause the area around the spring and the lake is a sacred area (Figure 3, 4 and 5). Sacred forest is a tradition of forest protection with public participation (Khan et al. 2008), so it is fitting to be used in the core zone of the national park (Kosmaryandi 2012).

Manggarai ethnic communities put the settlement on the flat area. Around the house is a yard (roas) with an area of about half a hectare planted with coffee, cloves, vanilla and food crops, i.e. muku (Musa paradisiaca), tete haju (Marihot utilisima), tete wase (Ipomoea batatas), padut (Carica papaya), uwi (Dioscorea sp) and plants that grow naturally as raci (Areca catecu) and teno (Mellochia umbellata).

Communal gardens for agroforestry (lingko) are located on the hills and lingko for rice plantation is along the river banks.
Kosmaryandi (2005) found the same ecological wisdom in Minangkabau community. The community has an ecological wisdom to keep the environment of landslides through experience so that the hills for agroforestry are far from settlement. Wae Rebo village community since 2014 decided to prohibit its citizens to plant rice fields on the slope of the land while the rice needs met from outside the village. Cultivation is done organically as well as traditional forest communities in Indonesia, such as: the Sasak people in Lombok Utara (Singha 2014), Baduy Banten (Hidayati 2013) and the community surrounding Wonosadi Forest, Gunung Kidul (Purnomo et al. 2012).

Manggarai the land management system can still be applied to vast territory for the needs of agricultural land. Wae Rebo community still have rotation crop on the farm which will revert to forest when fallow. Secondary forest called "rami" is an agricultural reserve that used for the purpose of shifting cultivation.

Wae Rebo community has not been working all the arable land in the enclave. The communal land that do not yet have a name is a reserve for arable land which is overgrown with shrubs. The area is quite 
steep topography causes people decide to not grow rice in the fields. People buy or plant rice in combo village, the area in the outside of the enclave.

Wae Rebo sacred area is wooded plateau, springs and canyons. Five sacred area on the north village entirely within the borders of the village. Manggarai people believe that the spirit of ancestors are in the north so that Wae Rebo community do not do the enclave in the north border of the sacred area.

Every village in Manggarai district always has a long history of the area that were abandoned due to landslides, flat area that is cramped and remote locations. The area is currently become a forest and is a source of conflicting claims of land ownership with the manager of forest area. Sources of conflict is the claims of land ownership that forest pal boundaries do not coincide with pal Netherlands resulting in the expansion area to the garden belongs to the people. The community will still working on the garden around the boundary of the forest area and consider it as their culture and called it " $h a-$ rat kope", it means wages for keeping forest area. The limited arable land of the division of communal lands because of the increasing number of people make the community began working on less fertile land, secluded and located on steep terrain and that is not a communal land, it called "tobok".

Communal land (lingko) have aesthetic value because of its shape like a cobweb. When in the middle there is a place of worship, it called "lingko rame" and when there is no place of worship is called "lingko bon" and when the garden shaped like a rectangular, it called "lingko neol". Lingko shaped like a spider's web made by an elderly called tu'a teno as a unique method of land apportionment. Tu'a teno put the twig of teno tree (Mellochia umbellata) in the center of "lingko", dividing lingko from the center point by putting wheels of a circle with spokes like a bicycle wheel. Tu'a teno divide the communal land with a size measurement of tu'a teno fingers. Part of thumb called "moso rembo" for tu'a golo and tu'a teno inherit forefinger it called "moso koe". Part of tilted finger called "moso iret" thre are the middle finger is tilted for "tu'a panga", ring finger is tilted for children of tu 'a teno and tu'a golo and ring fingers are tilted for others.

Land use with a shape like a spider's web was originally an agroforestry system with basic food are tubers that grow on the bottom of the garden. Plantation for agroforestry is not done with clearcut the entire tree, but purposely leaves of wild trees as a shade of coffee tree. Making rice fields carried out at about the era of 1950 . The gardens are communal property that are shared socially just done aesthetically and in line with the concept of sustainable use.

The unique system of land distribution according to the community is in addition to the principle of fairness in the distribution of communal land is also to cover the land surface that makes it difficult for boar to enter the garden to damage crops. In one "lingko" is divided into several sections triangular called "moso". Lingko center called Lodok and the outer limits called "cicing". Boundaries between "moso" called langang marked by the planting nao (Cordiline terminalis) or by digging the ditch.

In the region of the town Ruteng, Manggarai regency capital, land distribution system cobwebs can still clearly visible in the photo google map (Figure 7). Implementation of ceremonies in the center of "lingko rame", still remain to be done even with the costs shared between natives and migrants in traditional village. This proves that the physical changes do not change the function of the communal land.

Although ecological conditions are less favorable for agricultural land as territory of a steep valley, high rainfall intensity, acid soil, farmers Manggarai has been successfully managing the land as their owned of cultural landscape. Land management is done by the zoning system which among other things serves as a sacred area which is only used for traditional ceremonies.

Traditional land management of Manggarai community still retained because of communal kinship and social ties and traditional ritual that has local religious values that are still be adhered. Another reason is the geography of mountains with slopes greater than $60 \%$ would be more pro- 


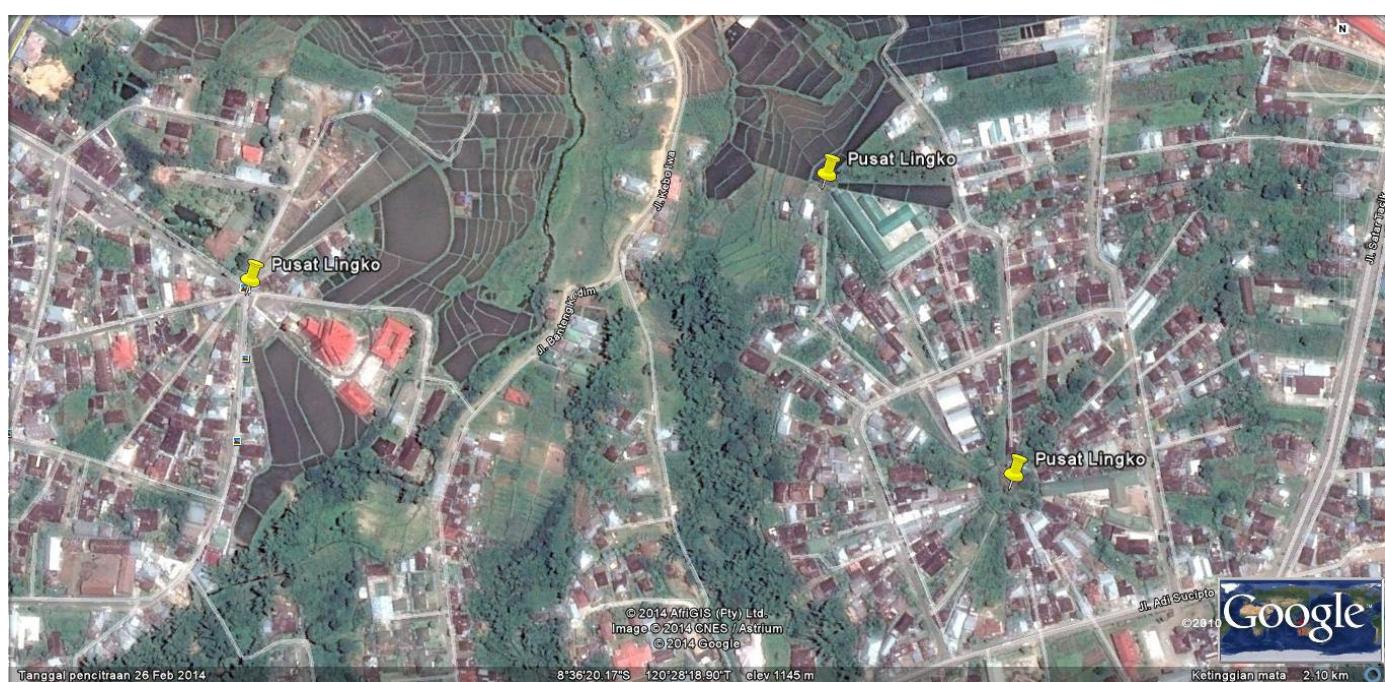

Source: Google Map accessed on 25 August 2015

Figure 7. The Development of Ruteng town retains the shape of cobwebs though experiencing physical development

fitable if land traditionally managed.

The supporting to communities, the manager of conservtion area should give an appropriate tree for coffee shade, thereby reducing the pressure on forest use to meet the needs of lumber. The areas that have been deforested duly strived to be replanted with native species that had previously been grown in the area. Pressure on forests for commercial firewood should be the government's attention to shift to the use of fuel that is more environmentally friendly. The fulfillment of timber should be from the garden outside the forest area.

The role of local institutional of Manggarai community will decrease with changes in lifestyle influence of modernization (Lawang 2004, p.116-132) and also the decline of local knowledge in the management of land and it is becoming a threat to the traditional conservation practices. Another challenge is the density of agrarian with a growing number of people who cause parts of arable land in communal land will be more narrow that affect the pattern of unsustainable land management.

Gardening as a main livelihood should get a referral to an intensification of the orientation on the market and production due to the extension of agricultural land affects the reduction of forest cover. Intensification is one option to meet the food needs of the Manggarai community in the mountains of Ruteng. Conservation programs should not be directed to alienate the public from the forest, but to develop the potential that exists in the forest such as for example the development of traditional medicinal plant market-oriented.

\section{CONCLUSION}

Manggarai community has made conservation through forest management practices and traditional land who have religious values that are still be adhered locally. Nature and the environment is seen as the result of a marriage between heaven and earth called "anak rona" or descendant of the woman that must be respected. The reverence of nature that cause forest management and sustainable traditional land (conservation) and its use is governed by traditional social structures and kinship. Forest management should accommodate traditional community interest by integrating traditional land management practices into conservation.

\section{REFERENCES}

Agarwal, B., 2009. Gender and forest conservation: The impact of women's participation in community forest governance. Ecological economics, 68(11), pp.2785-2799.

Anderson, P.J., Putz, F.E., 2002. Harvesting and Conservation: are Both Possible for the Palm, Iriartea deltoidea ?. Forest Ecology and Management, 170, pp.271-283. 
Berkes, F. and Turner, N.J., 2006. Knowledge, learning and the evolution of conservation practice for social-ecological system resilience. Human Ecology, 34(4), p.479.

Boesi, A., 2014. Traditional Knowledge of Wild Food Plants in a few Tibetan Communities. Journal of Ethnobiology and Ethnomedicie. 10(75), pp.1-19.

Brook, R.K. and McLachlan, S.M., 20o8. Trends and prospects for local knowledge in ecological and conservation research and monitoring. Biodiversity and Conservation, 17(14), pp.35013512.

Camacho, L.D., Combalicer, M.S., Yeo-Chang, Y., Combalicer, E.A., Carandang, A.P., Camacho, S.C., de Luna, C.C. and Rebugio, L.L., 2012. Traditional forest conservation knowledge/ technologies in the Cordillera, Northern Philippines. Forest policy and economics, 22, pp.38.

Charnley, S., Fischer, A.P. and Jones, E.T., 2007. Integrating traditional and local ecological knowledge into forest biodiversity conservation in the Pacific Northwest. Forest Ecology and Management, 246(1), pp.14-28.

Coombe, R.J., 2005. Protecting traditional environmental knowledge and new social movements in the americas: Intellectual property, human right, or claims to an alternative form of sustainable development. Fla. J. Int'l L., 17, p.115.

Dassir, M., 2008. Pranata Sosial Sistem Pengelolaan Hutan Masyarakat Adat Kajang. Jurnal Hutan dan Masyarakat 3(2), pp.135-147.

Dewa, R., 1993. Perubahan Pranata Pengelolaan Lahan pada Komunitas Peladang di Nusa Tenggara Timur: Kasus Lio dan Iwanggete di Pulau Flores. Journal of Indonesian Human Ecology 1(1), pp.37-57.

Djuwansah, M., Suriakusumah, A., 1998. Soil of Ruteng Nature Recreation Park. Lembaga Ilmu Pengetahuan Indonesia, Bogor .

Herrmann, T.M., 2006. Indigenous knowledge and management of Araucaria araucana forest in the Chilean Andes: implications for native forest conservation. Biodiversity and Conservation, 15(2), pp.647-662.

Hidayati, S., 2013. Analisis Penerapan Pengetahuan Etnobotani Masyarakat Baduy dalam Ketahanan Pangan (Thesis). Institut Pertanian Bogor, Bogor.

Iswandono, E., Zuhud, E.A.M., Hikmat, A. and Kosmaryandi, N., 2015. Integrating Local Culture into Forest Conservation: A Case Study of The Manggarai Tribe in Ruteng Mountains, Indonesia. Jurnal Manajemen Hutan Tropika, 21(2), p. 55 .

Iswandono, E., Zuhud, E.A.M., Hikmat, A. and Kosmaryandi, N., 2015. Pengetahuan etnobotani suku Manggarai dan implikasinya terhadap pemanfaatan tumbuhan hutan di Pegunungan Ruteng. Jurnal Ilmu Pertanian Indonesia, 20(3), pp.171-181.

Khan, M.L., Khumbongmayum, A.D. and Tripathi, R.S., 2008. The sacred groves and their significance in conserving biodiversity an overview. International Journal of Ecology and Environ- mental Sciences, 34(3), pp.277-291.

Koentjaraningrat. 2002. Pengantar Ilmu Antropologi. Rineka Cipta, Jakarta.

Kosmaryandi, N. 2005. Kajian Penggunaan Lahan Minangkabau berdasarkan Kondisi Tanahnya. Media Konservasi, 10(2), pp.77-81.

Kosmaryandi, N., 2012. Gagasan Baru Zonasi Taman Nasional: Sintesis Kepentingan Konservasi Keanekaragaman Hayati dan Kehidupan Masyarakat Adat. Jurnal Manajemen Hutan Tropika, 18(2), pp.69-77.

Lawang, R,M,Z., 2004. Stratifikasi Sosial di Cancar Manggarai, Flores Barat. UI Press, Jakarta.

Persha, L., Agrawal, A. and Chhatre, A., 2011. Social and ecological synergy: local rulemaking, forest livelihoods, and biodiversity conservation. science, 331(6024), pp.16o6-16o8.

Reyes-García, V., Guèze, M., Luz, A.C., PanequeGálvez, J., Macía, M.J., Orta-Martínez, M., Pino, J. and Rubio-Campillo, X., 2013. Evidence of traditional knowledge loss among a contemporary indigenous society. Evolution and Human Behavior, 34(4), pp.249-257.

Senoaji, G., 2011. Perilaku Masyarakat Baduy dalam mengelola lahan dan lingkungan di Banten Selatan. Jurnal Humaniora, 23(1), pp.14-25.

Sinu, I., Leki, S., Klau, F., Nur, M., Wiendiyanti, Sau, P., 1999. Pengkajian Dampak Sosial Ekonomi dan Budaya sebagai Pendukung Pengelolaan Taman Wisata Alam Ruteng, Nusa Tenggara Timur. Fakultas Pertanian Universitas Nusa Cendana - PKAT, Ruteng.

Sugiyono. 2010. Metode Penelitian Administrasi. CV Alfabeta, Bandung.

Trainor. C., Lesmana, D., 20oo. Gunung Berapi, Burung-burung Khas, Tikus Raksasa dan Tenun Ikat yang Menawan. BirdLife International Indonesia Programme, Bogor.

Vasques, A.S., Caballero, J., Meave, J.A., Chiang, F., 2013. Cultural Change and Loss of Ethnoecological Knowledge among the Isthmus Zapotecs of Mexico. Journal of Ethnobiology and Ethnomedicine, 9(40), pp.1-10.

Verheijen, J.A.J., 1977. Logat Nama-nama Tumbuhan di Manggarai-Flores. Regio SVD, Ruteng.

Wawo, A.H., 1998. An ethnobotanical Study of People Around Ruteng Nature Recreation Park, Flores Island. Lembaga Ilmu Pengetahuan Indonesia, Bogor.

Weyerhaeuser, H., Wilkes, A. and Kahrl, F., 2005. Local impacts and responses to regional forest conservation and rehabilitation programs in China's northwest Yunnan province. Agricultural Systems, 85(3), pp.234-253.

Wijayanto, N., 2002. Analisis strategis sistem pengelolaan repong di pesisir Krui, Lampung. Manajemen Hutan Tropika, 8(1), pp.39-49.

Zapf, M.K., 2005. The spiritual dimension of person and environment: Perspectives from social work and traditional knowledge. International Social Work, 48(5), pp.633-642.

Zent, S., 2009. Methodology for Developing a Vitality index of Traditional Environmental Knowledge. Caracas: Instituto Venezolano de Investigaciones Cientificas. 